\title{
PHYSICOCHEMICAL PROPERTIES, NUTRITIONAL AND ANTINUTRITIONAL COMPOSITION OF PULP AND PEEL OF THREE MANGO VARIETIES
}

\author{
Deepa M Madalageri ${ }^{1}$, Pushpa Bharati ${ }^{2} \&$ Udaykumar Kage $^{3}$ \\ ${ }^{1}$ Assistant Professor, Department of Food Science and Nutrition, College of Rural Home Science, \\ University of Agricultural Sciences, Dharwad, Karnataka, India \\ ${ }^{2}$ Departmenrt of Food Science and Nutrition College of Rural Home Science, \\ University of Agricultural; Sciences, Dharwad, Karnataka, India \\ ${ }^{3}$ Department of Plant Science, McDonald Campus, McGill University, Karnataka, India
}

\begin{abstract}
The physical and chemical properties of fruits are important indicators of their external and internal quality and also form the basis for studying chemical, nutritional and biochemical composition. Among the three varieties of mango, the physical properties of Totapuri were significantly higher compared to Alphonso and Kesar varieties. The total waste generated including peel and kernel was significantly higher in Totapuri (76.50 g) compared to Alphonso and Kesar (57.30 and $56.50 \mathrm{~g}$, respectively). The ascorbic acid and pectin was significantly higher in peel.(25.99 mg/100g and $18.92 \%)$ compared to pulp $(18.87 \mathrm{mg} / 100 \mathrm{~g}$ and $4.59 \%)$ respectively. The fat, crude fiber, total minerals, Calcium, phosphorous, zinc, iron, manganese and copper were significantly higher in peel compared to pulp irrespective of varieties. Phytic acid and oxalates were significantly higher in peel (25.48 mg/100g and $7.24 \%)$ compared to pulp(0.61 mg/100g and $4.31 \%)$. The green gram laddu incorporated with 15 per cent mango peel was highly acceptable by panels with high acceptability index 95.24 per cent. The green gram laddu prepared with kesar peel had higher sensory scores compared to alphonso and totapuri. The laddu prepared with mango peel contained higher $\beta$-carotene and dietary fiber compared to the green gram laddu.
\end{abstract}

KEYWORDS: Mango, Proximate, Laddu, Fiber and Carotene

Received: May 09, 2017; Accepted: May 31, 2017; Published: Jun 13, 2017; Paper Id.: IJESRJUN201710

\section{INTRODUCTION}

India ranks second in production of fruits in the world, after China. During 2009-10, India produced 71.52 million metric tonnes of fruits with the area under cultivation of 6.33 million hectares. During 2010-11, India exported fruits worth of 2635 crores. Due to the short shelf life of these crops as much as 30-35 per cent of fruits perish during harvest, storage, grading, transport, packaging and distribution. Although India has a strong raw material base, it has been unable to tap the potential for processing and value addition to fruits. Only about two per cent of the fruits are processed into value added products, which is much lower when compared to other countries.Karnataka produces about 17.80 million MT of horticultural crops from an area of 1.87 million ha accounting to 7.40 per cent of total horticultural production in the country. Major share of production is from fruits (35.25\%). Around 5.67 lakh MT of fruits have been traded in organized markets with average price of ₹17.47/kg(Singha, Choudhary, \& Vishnu, 2014). 
Mango (Mangifera indica L.), which belongs to the family Anacardiaceae, order Rutales, is one of the most important tropical fruits marketed in the world and is ranked fifth in total world production of major fruit crops (FAO, 2006). It is grown naturally or cultivated mainly in tropical and subtropical regions. Karnataka is the third largest mango producing state in the country and accounts for 11.7 per cent of mango production. The state is producing about $1.78 \mathrm{~m}$. MT from an area of $0.16 \mathrm{~m}$. ha. The productivity of mango in the state is $11.0 \mathrm{MT} / \mathrm{ha}$. The production is concentrated in Kolar, Tumkur and Bengaluru districts. The commercial varieties grown in the state are Alphonso, Totapuri, Banganapalli, Pairi, Neelum and Mulgoa. Around 0.14 lakh MT of mango has been traded in organized markets with average price of ₹ $5.90 / \mathrm{kg}$ (Singha et al., 2014). Mango is also recommended for commercial planting as it has a high demand for direct consumption and for processing because of its pleasant flavor and unique taste. Mango, being a highly perishable seasonal fruit,suffers significant post-harvest wastage during its peak season, mainly as a result of inadequate handling. Poor post harvest technology is one of the major constraints to annual production, accounting for nearly 60-80\% of losses (Djantou, Mbofung, Scher, \& Desobry, 2007; Joseph \& Abolaji, 1997). Extensive research in the area of plant breeding has generated hundreds of cultivars, the fruits of which show a pronounced diversity in size, color, flavor, seed size, and composition (Stafford, 1983). As mango is a seasonal fruit, it is processed into various products such as puree, nectar, leather, pickles, canned slices, etc., which have worldwide popularity (Loeillet, 1994). During the processing of mango, a massive quantity of peel is generated and is considered a waste by-product. Also, its disposal is a major problem, causing environmental pollution. The peel constitutes about 15 to 20 percent of the whole mango fruit. Peels have been shown to be a good source of nutrients, polyphenols, flavonoids, carotenoids, dietary fibres and other bioactive compounds that possess various beneficial effects on human health (C. M. Ajila, Bhat, \& Prasada Rao, 2007; J. Larrauri, 1999; J. A. Larrauri, Rupérez, Borroto, \& Saura-Calixto, 1996; Luthria, 2012; Wolfe, Wu, \& Liu, 2003).Some of these compounds exhibit good antioxidant property(C. M. Ajila, Naidu, Bhat, \& Rao, 2007).

Storage of agricultural materials and for converting these materials into food and processed product requires an understanding of their physical properties. Size and shape are most often used when describing grains, seeds, fruits, and vegetables. The shape and physical dimensions are important in sorting and sizing of fruits, and determine how many fruits can be placed in shipping containers or plastic bags of a given size. Quality differences in fruits, vegetables, grain and seeds can often be detected by differences in density. Quality is defined as the absence of defects or degree of excellence and it includes appearance, colour, shape, injuries, flavor, taste, aroma, nutritional value and being safe for the consumer (Abbott, 1999). Due to a higher market demand as for high-quality products, the juice and pulp industries have been looking for fruits with better internal and external features, including fruit length and width; fruit weight; pulp, seed and peel percentages per fruit; number of seeds per fruit; seed size and peel diameter; soluble solids ( ${ }^{\circ}$ Brix); titratable acidity (\%); vitamin $\mathrm{C}$ content (mg/100g of fresh fruit); pulp $\mathrm{pH}$ and soluble solids/titratable acidity ratio. The maintenance of fruit quality characteristics (internal and external) demands postharvest handlings, such as: preventing mechanical injury, water loss and disease development, limiting unwanted physiological changes and preventing chemical and microbial contamination (Cook, 1999).

Physical properties of food ingredients are some of the properties, which define their visual characteristics and basic functionality. The physical and chemical properties of fruits are important indicators of their external and internal quality and decisive factors for the accomplishment of market demands. Information on physical characters of fruit forms the basis for studying chemical, nutritional and biochemical composition. Studies on fruit characterization can be helpful in selecting better quality fruits. Physical characteristics like size, shape, weight, volume etc. act as an important tool to 
properly relate the nutritional, chemical and bioactive compounds in the fruits (Cavalcante, Martins, de Sousa Miranda, \& Cavalcante, 2012).

Since, the fruit waste products selected for the present study do not belong to the category of foods, which are well known and often used, it was essential to record basic physicochemical characteristics, nutrient and antinutrient composition that would be beneficial in understanding the nature of mango peel. This would also help to utilise this potential mango waste for the health and nutrition security. Laddus are most popular sweets all over India. Varieties of laddu using cereal, pulse flour and nuts are prepared throughout India. A wide variation of laddu is available and according to their palate the laddus are prepared. In recent days laddus are available commercially at all sweets marts. Green gram laddu is common, most accepted easily digestible product having pleasant roasted aroma of green gram with sweetness of jaggery. In this study an attempt was made to incorporate mango peel powder in green gram laddu for value addition. The present study was conducted to evaluate the physicochemical properties, nutritional, antinutrient content of pulp and peel of three mango varieties and to utilize the mango peel in product development.

\section{MATERIALS AND METHODS}

\section{Physical Properties of Whole Fruits}

Whole mango fruits were used for measuring physical properties such as weight, volume, bulkdensity, length, breadth, width and circumference. Ten individual fruits were weighed using the digitalized sensitive balance average was calculated and expressed in Kilograms $(\mathrm{kg})$. Volume of ten individual fruits was determined by water displacement method and average calculated. The results were expressed in milliliter $(\mathrm{mL})$.Bulk density of the fruit was calculated using the readings of weight and volume Length, breadth and width of the ten mangoes were obtained using the digital vernier caliper and expressed in millimeter $(\mathrm{mm})$. Lengthwise circumference of fruit was measured by passing a thread around the fruit in upper, middle and lower part. The average of three measurements was calculated and expressed in centimeter $(\mathrm{cm})$.Width wise circumference was measured using thread by passing around the fruit in upper, middle and lower part along the width of the fruit. The average of ten was calculated and expressed in centimeter $(\mathrm{cm})$.

\section{Processing of Mango}

Three mango varieties namely Alphonso, Kesar, Totapuri collected from fruit outlets, Dharwad were washed separately in running tap water and wiped using a clean dry muslin cloth. The peel was separated using a sharp knife and the underlying pulp was removed by gently scraping with the knife's blunt edge. The kernel was separated from adhering pulp using a sharp knife. The weight of pulp, peel and kernel was recorded using digitalized sensitive balance and percentages calculated. The pulp was homogenized using a hand-held blender whereas the peel was cut into small pieces before being dried using a cabinet drier maintained at $50 \pm 2^{\circ} \mathrm{C}$ for $12 \mathrm{~h}$. Following drying, the peels were ground to a fine powder which was packed in polyethylene pouches and stored at $-20^{\circ} \mathrm{C}$ for further chemical analysis.

\section{Total Waste Generated from Mango}

Total waste generated was calculated using the following formula Total waste generated $=$ Weight of the $($ peel + kernel) 


\section{Edible Waste Generated from Mango}

Percent edible waste generation of mango was calculated using the following formula

$$
\text { Edible waste generated }(\%)=\frac{\text { Weight of the (ped }+ \text { ke:nel) }}{\text { Weight of whole fruit }} \times 100
$$

\section{Total Waste Generated}

Percent waste generation of each mango variety was calculated using the following formula

$$
\text { Total waste generated }(\%)=\frac{\text { Weight of the total waste }}{\text { Weight of whole fruit }} \times 100
$$

\section{Chemical Parameters of Fresh Fruit}

Moisture content of fresh three mango varieties was analyzed by oven drying method. Pulp and peel were dried in oven at a temperature of $50-55^{\circ} \mathrm{C}$ until constant weight was obtained (Ranganna, 1986) and percentages were calculated. The Total Soluble Solids (TSS) of three varieties of mango pulp was recorded using Erma Hand Refractometer. Titratable acidity was determined by titrating against $0.1 \mathrm{~N}$ sodium hydroxide solution using phenolphthalein as an indicator (Ranganna, 1986). Results were expressed in terms of percent citric acid. The pH of three varieties of mango pulp was recorded with the help of pocket $\mathrm{pH}$ meter (Model, H196107 Hanna instruments $\mathrm{pH} \mathrm{cp}$ ). The fruits were macerated and used for measuring the $\mathrm{pH}$. The total and reducing sugars were determined as per the procedure of Nelson-Somogyi (Ranganna, 1986) Non- reducing sugar was computed by subtracting reducing sugar from total sugar and multiplying with 0.95 a constant conversion factor

The microwave extraction of pectin was performed according to the methods described by (Maran, Sivakumar, Thirugnanasambandham, \& Sridhar, 2014; Wang et al., 2007).

\section{Nutrient Composition}

The selected three varieties of mango pulp and peel were analyzed for proximate composition viz, moisture, crude protein, ash, crude fat, crude fibre using AOAC procedure and carbohydrate was computed. In addition dietary fibre, vitamins and minerals were estimated. All analysis was done in triplicate. The calorific value was calculated by summing up the values obtained by multiplying carbohydrate, protein and fat with Atwater constants. The values of carbohydrate, crude protein and crude fat were multiplied with 4, 4 and 9, respectively and expressed as $\mathrm{kcal}^{100 \mathrm{~g}^{-1}}$. The soluble, insoluble and total dietary fiber fractions were analyzed by anenzymatic method (Anon, 1995). Ascorbic acid content was determined by thevolumetric method. (Ranganna, 1986). Total and $\beta$ Carotene was estimated by HPLC method. (Krishna et al., 2001). Calcium was precipitated as calcium oxalate. The precipitate was dissolved in hot dilute $\mathrm{H}_{2} \mathrm{SO}_{4}$ and titrated against standard potassium permanganate (Oser, 1965). The trace elements (iron, zinc, copper and manganese) were estimated by wet digestion using a triacid mixture. A known aliquot of the test sample was suitably diluted and micronutrients in the test sample $(\mathrm{Cu}, \mathrm{Mn}, \mathrm{Zn}$ and $\mathrm{Fe})$ were determined using Atomic Absorption Spectrophotometer (model: AAS GBS Avanta). 


\section{Antinutrient Analyses}

The estimation of phytic acid was based on the principle that the phytate is extracted with trichloroacetic acid and precipitated as ferric salt (Wheeler \& Ferrel, 1971). The iron content of the precipitate was determined colorimetrically and the phytate phosphorous content calculated from this value assuming a constant Fe : 6 molecular ratios in the precipitate. Phytates were estimated as phytic and the phytate phosphorus was obtained. Oxalates were extracted with hydrochloric acid, precipitated as calcium oxalate from the deproteinized extract and were estimated by subsequent titration with potassium permanganate(Dye, 1956).

\section{Value Addition to Mango Peel \\ Procurement of Ingredients}

Green gram flour, sugar, ghee and mango was procured in bulk from local market of Dharwad

\section{Processing of Mango Peel}

The processing of all the three mango varieties was done separately. The peel was separated using a sharp knife and the underlying pulp was removed by gently scraping with the knife's blunt edge. The peel was dried in a cabinet dryer at $40^{\circ} \mathrm{C}$ until the peel is moisture free. Lower temperatures were used to dry mango peel to retain the beta carotene content. The dried peel was powdered in pestle and mortar and packed in a polyethylene pouches and stored at $-20^{\circ} \mathrm{C}$ for further use.

\section{Protocol of Mango Peel Incorporated Green Gram Laddu}

Green gram flour was roasted with the addition of ghee in a low flame until an aroma developed and sugar powder was added and a different proportion of mango peel $(2.5,5$ and $10 \%)$ was incorporated. The optimized value added products were analysed for proximate composition and trace minerals.

\section{Sensory Evaluation}

The products were subjected to organoleptic evaluation using 9 points hedonic scale (Amerine, Pangborn, \& Roessler, 1965) by trained sensory panel of the Food Science and Nutrition Department (UAS-Dharwad).

\section{Statistical Analysis}

Statistical analysis was carried out using SPSS package. Student's 't' test, one-way and two-way ANOVA were used to assess the significant differences. Duncan's new multiple range test and correlations using Pearson's correlation coefficient were carried out.

\section{RESULTS AND DISCUSSIONS}

\section{Physical Properties of Whole Fruits}

The physical properties of mango varieties are depicted in Table 1. The weight and volume of Totapuri $(287.00 \mathrm{~g}$ and $261.50 \mathrm{ml})$ were significantly higher than Alphonso $(231.90 \mathrm{~g}$ and $214.40 \mathrm{ml})$ followed by Kesar $(200.90 \mathrm{~g}$ and188.80 $\mathrm{ml}$ ), respectively. However, the bulk densities of all three varieties of mango were statistically on par with each other $(1.098,1.082$ and $1.0064 \mathrm{~g} / \mathrm{ml})$. Fruits of Totapuri variety were significantly longer $(12.36 \mathrm{~cm})$ than Alphonso $(9.464 \mathrm{~cm})$ and Kesar $(9.565 \mathrm{~cm})$, the width and breadth did not differ significantly $(7.08,7.34,6.566$ and $6.66,6.06,5.80 \mathrm{~cm})$, respectively. The weight of the pulp $(190.30 \mathrm{~g})$ and peel $(43.80 \mathrm{~g})$ of Totapuri variety was significantly higher than the 
Alphonso (168.10 and $32.00 \mathrm{~g}$, respectively) while, Kesar recorded significantly lower values (140.20 and $25.70 \mathrm{~g}$, respectively). The Alphonso (25.30) variety contained smaller kernel than Totapuri (32.70g) and Kesar (30.80g) which were on par with each other. The total waste generated including peel and kernel was significantly higher in Totapuri (76.50 g) compared to Alphonso and Kesar (57.30 and $56.50 \mathrm{~g}$, respectively).

\section{Chemical Properties of Whole Fruits}

Table 2 depicts the chemical composition of pulp and peel of mango varieties. The $\mathrm{pH}$ of the pulp of Kesar was higher (4.53) than Totapuri (4.23) followed by Alphonso (4.10), however, this difference was statistically on par. Titratable acidity was significantly higher in pulp $(0.25 \%)$ than in peel $(0.12 \%)$, irrespective of variety. Among pulp of different varieties Alphonso pulp $(0.29 \%)$ had significantly higher titratable acidity than Totapuri $(0.25 \%)$ followed by Kesar $(0.22 \%)$. A similar trend was observed in the peel of Alphonso $(0.13 \%)$, Totapuri $(0.12 \%)$ and Kesar $(0.12 \%)$. With regard to the total soluble solids, the Kesar pulp had significantly higher (21.93\%) compared to Alphonso (19.80\%) and Totapuri (17.17\%). Earlier studies of (C. M. Ajila, Bhat, et al., 2007; C. M. Ajila, Naidu, et al., 2007)reported that the TDF, IDF and SDF content in peels from different varieties of mango fruits at different stages of maturity varied from 45-78, 29-50 and 15-28, per cent respectively. Ascorbic acid was significantly higher in peel (25.99 mg/100g) compared to a pulp $(18.87 \mathrm{mg} / 100 \mathrm{~g})$ irrespective of variety. Irrespective of a portion of fruit Alphonso contained significantly higher (24.31 $\mathrm{mg} / 100 \mathrm{~g})$ ascorbic acid compared to Kesar $(22.01 \mathrm{mg} / 100 \mathrm{~g})$ and Totapuri $(20.97 \mathrm{mg} / 100 \mathrm{~g})$. When compared between peel between varieties the Alphonso (28.39 mg/100g) contained higher ascorbic acid than Kesar (25.50 mg/100g) followed by Totapuri $(24.08 \mathrm{mg} / 100 \mathrm{~g})$. Total, reducing and non-reducing sugars were significantly higher in Alphonso pulp (19.32, 5.56 and $13.76 \mathrm{mg} / 100 \mathrm{~g})$ compared to Kesar (18.52, 15.75 and $4.15 \mathrm{mg} / 100 \mathrm{~g})$ and Totapuri (13.00, 3.47 and 9.53 $\mathrm{mg} / 100 \mathrm{~g})$. The pectin content was significantly higher in peel $(18.92 \%)$ compared to a pulp (4.59\%) irrespective of variety. The pectin content was significantly higher in Kesar (12.99\%) than Alphonso (11.58\%) followed by Totapuri (10.71\%) irrespective of a portion of the fruit. (C. Ajila, Rao, \& Rao, 2010)Ajila and co-workers (2010a) also reported the similar content of fibre and pectin. Recently, a screening study of 14 mango cultivars had demonstrated the content and degree of esterification of mango peel pectins to range from $12 \%$ to $21 \%$ and $56 \%$ to $66 \%$, respectively (Berardini, Knödler, Schieber, \& Carle, 2005).

\section{Nutrient Composition}

The proximate composition of mango varieties and their edible waste is presented in Table 3. A significant difference was observed between a portion of fruit (pulp and peel), between variety and interaction between portion and variety at $\mathrm{p} \leq 0.01$ level of significance for moisture, fat, minerals, carbohydrate and calories. The moisture content was significantly higher in pulp $(77.41 \%)$ compared to peel $(10.43 \%)$ irrespective of varieties. Among varieties, Alphonso had significantly higher moisture $(43.01 \%)$ compared to Kesar $(39.53 \%)$ and Totapuri $(37.54 \%)$. The protein content was not significantly different in mango pulp $(0.77 \%)$ and peel $(0.67 \%)$ irrespective of varieties. Whereas, between the varieties Alphonso had higher $(0.79 \%)$ protein content than Kesar $(0.67 \%)$ and Totapuri though not statistically significant. The fat, minerals, crude fiber and carbohydrate contents were significantly higher in peel (3.59, 3.49, 10.61 and $71.19 \%$, respectively) when compared to a pulp $(0.75,1.89,0.52$ and $18.67 \%$, respectively) irrespective of variety and interactions. Among the varieties, the fat content was significantly higher in Totapuri (2.33\%) compared to Kesar (2.19\%) and Alphonso (1.99\%) irrespective of pulp and peel. The total mineral content was significantly higher in Alphonso (2.87\%) compared to Kesar and Totapuri (2.64 and 2.57\%) irrespective of pulp and peel. The crude fiber was not significantly 
different between the varieties irrespective of pulp and peel. The carbohydrate content was significantly higher in Kesar (49.46\%) compared to Totapuri (48.82\%) followed by Alphonso (45.55\%) irrespective of a portion of the fruit. Peel possessed significantly higher energy $(320 \mathrm{Kcal} / 100 \mathrm{~g})$ compared to a pulp $(85.00 \mathrm{Kcal} / 100 \mathrm{~g})$ irrespective of varieties. The Totapuri variety of mango had the significantly higher energy $(230 \mathrm{Kcal} / 100 \mathrm{~g})$ compared to Kesar $(220 \mathrm{Kcal} / 100 \mathrm{~g})$ and Alphonso $(203 \mathrm{Kcal} / 100 \mathrm{~g})$ irrespective of a portion of the fruit. The proximate composition of mango fruit pulp was $81 \%$ moisture, $0.6 \%$ protein, $0.4 \%$ fat, $0.4 \%$ minerals, $0.7 \%$ fibre and $16.9 \%$ carbohydrate as reported by (Gopalan, Rama

Sastri, \& Balasubramanian, 1971). The proximate composition reported was comparable to the earlier reported values in the peels of Badami and Raspuri varieties of mango (C. M. Ajila, Bhat, et al., 2007).

Table 4 represents the mineral content of pulp and peel of mango varieties. There was a significant difference in the calcium, phosphorus, iron manganese and copper between the portion of the fruit (pulp and peel). The mango peel contained significantly higher amounts of calcium, phosphorus, iron, manganese and copper $(18.05,19.82,0.49,0.37$ and $0.07 \mathrm{mg} / 100 \mathrm{~g})$ when compared to a pulp $(12.77,15.73,0.28,0.15$ and $0.04 \mathrm{mg} / 100 \mathrm{~g})$, irrespective of varieties and interaction between a portion of fruit and varieties. Whereas, a significant difference was not observed between pulp $(0.19 \mathrm{mg} / 100 \mathrm{~g})$ and peel $(0.23 \mathrm{mg} / 100 \mathrm{~g})$ for zinc. Kesar variety had the significantly higher amount of calcium and iron (15.61 and $0.46 \mathrm{mg} / 100 \mathrm{~g}$ ) compared to Totapuri $(15.18$ and $0.31 \mathrm{mg} / 100 \mathrm{~g})$ and Alphonso (15.43 and $0.37 \mathrm{mg} / 100 \mathrm{~g}$ ) irrespective of a portion of fruit and interaction. The phosphorus was significantly higher in Alphonso $(18.31 \mathrm{mg} / 100 \mathrm{~g})$ compared to Kesar and Totapuri (17.73 and $17.28 \mathrm{mg} / 100 \mathrm{~g})$.Significantly, higher amounts of manganese $(0.33 \mathrm{mg} / 100 \mathrm{~g})$ were recorded in Totapuri compared to Kesar $(0.26 \mathrm{mg} / 100 \mathrm{~g})$ followed by Alphonso $(0.21 \mathrm{mg} / 100 \mathrm{~g})$. The copper content was significantly higher in Kesar variety $(0.07 \mathrm{mg} / 100 \mathrm{~g})$ compared to other two varieties $(0.05$ and $0.05 \mathrm{mg} / 100 \mathrm{~g})$. There was no significant difference in the zinc content between the portion of fruit, varieties and interaction.

\section{Dietary Fiber}

Figure 1 shows the dietary fiber content of pulp and peel of mango varieties. Mango pulp had significantly lower insoluble, soluble and total dietary fiber (4.35, 3.33 and 7.68\%, respectively) compared to peel $(33.19,6.28$ and $39.47 \%$, respectively) irrespective of variety. Alphonso variety had significantly higher insoluble soluble and total dietary fiber (22.29, 5.73 and $28.02 \%$, respectively) compared to Kesar (18.55, 4.67 and 23.22\%, respectively) and Totapuri (15.47, 4.01 and $19.48 \%$, respectively) irrespective of a portion of fruit.

\section{The $\beta$-Carotene}

Figure 2 depicts the $\beta$ - carotene content of pulp and peel of mango varieties. The $\beta$ - carotene content was significantly higher in peel $(47.85 \mathrm{mg} / 100 \mathrm{~g})$ compared to pulp $(26.41 \mathrm{mg} / 100 \mathrm{~g})$ with irrespective of varieties, which was comparable to the carotenoid content reported in peel from Raspuri mango variety (3337 $\mu \mathrm{g} / \mathrm{g}$ ) by (C. Ajila et al., 2010; C. M. Ajila, Bhat, et al., 2007; C. M. Ajila, Jaganmohan Rao, \& Prasada Rao, 2010; C. M. Ajila, Naidu, et al., 2007).Significantly higher $\beta$-carotene in the Kesar $(51.92 \mathrm{mg} / 100 \mathrm{~g}$ ) compared to Alphonso (41.99 mg/100g) and Totapuri $(17.47 \mathrm{mg} / 100 \mathrm{~g})$ irrespective of portion of fruit.

\section{Antinutrient Content}

Significant difference existed in the phytic acid and oxalate content of the portion of the fruit and of the varieties at $\mathrm{p} \leq 0.01$ percent significance level (Table 5). The phytic acid was significantly higher in mango peel $(25.48 \mathrm{mg} / 100 \mathrm{~g}$ ) compared to a pulp $(0.61 \mathrm{mg} / 100 \mathrm{~g})$ irrespective of variety. The phytic acid content was significantly higher in Kesar 
variety $(17.17 \mathrm{mg} / 100 \mathrm{~g})$ compared to Alphonso $(13.06 \mathrm{mg} / 100 \mathrm{~g})$ followed by Totapuri $(8.90 \mathrm{mg} / 100 \mathrm{~g})$ irrespective of a portion of fruit. The oxalate content was significantly higher in mango peel (7.24\%) compared to a pulp (4.31\%) irrespective of varieties. Similar to phytic acid the oxalate content was significantly higher in Kesar (6.52\%) compared to Alphonso (5.14\%) followed by Totapuri (5.66\%) variety irrespective of a portion of fruit.

\section{Product Development and Optimisation}

Table 6 depicts the optimisation of incorporation of Kesar mango peel in green gram laddu. The green gram laddu incorporated with Kesar mango peel powder up to 15 per cent was significantly and highly acceptable and had received higher sensory scores for all attributes appearance, colour, texture, aroma, flavour, taste and overall acceptability $(8.20,8.30,8.50,8.60,8.80,8.80$ and 8.80, respectively). The acceptability index was very high (95.24\%). This level of incorporation had the pleasant flavour of mango which was liked by most of the consumers and the peel of the mango had a crunchy texture and gave the textural variation in smooth laddus. The laddu incorporated with 20 per cent of mango peel received significantly lower sensory scores though acceptable for appearance (8.00), colour (7.70), texture (7.80), aroma (7.60), flavour (7.70), taste (8.30), overall acceptability (8.33) and acceptability index (86.19). The 15 percent level of incorporation of mango peel in laddu was used for further study.

Table 7 shows the organoleptic evaluation of mango peel incorporated in green gram laddu. There was no significant difference in the appearance and taste of mango peel laddu prepared Alphonso (7.80), Kesar (8.20) and Totapuri (7.90). However the colour, texture, aroma, flavour and overall acceptability of laddu incorporated with Kesar peel (8.30, 8.50, 8.60, 8.80, 8.80 and 8.80, respectively) were significantly higher than Totapuri (7.70, 7.30, 7.50, 7.30, 7.60 and 7.70) and Alphonso (7.20, 6.60, 7.20, 7.40, 7.40 and 7.50, respectively). The acceptability index was noticeably higher for aKesar peel (95.24\%) followed by Totapuri (84.13\%) and Alphonso (80.80\%).This might be due to the pleasant flavour and texture of the kesar peel which was crispier while that of alphonso and totapuri was leathery.

Table 8 depicts the effect of incorporation of mango peel powder on nutrient composition of green gram laddu. The laddu prepared with mango peel contained higher $\beta$-carotene $(202.39 \mu \mathrm{g} / 100 \mathrm{~g}$ ), crude fiber fiber (5.55\%), Iron $(2.11 \mathrm{mg} / 100 \mathrm{~g})$ and copper $(.78 \mathrm{mg} / 100 \mathrm{~g})$ compared to the green gram laddu $(44.2 \mu \mathrm{g} / 100 \mathrm{~g}, 4.65 \%, 1.87 \mathrm{mg} / 100 \mathrm{~g} 0.67$ $\mathrm{mg} / 100 \mathrm{~g}$ ) respectively.

\section{CONCLUSIONS}

The peel is considered an edible tissue of the unripe mango fruit. Using unripe mango fruit with its peel, chutneys and pickles are prepared. On the other hand, peel of the ripe mango fruit, due to its leathery texture, is not too acceptable taste-wise; therefore, the peel is generally removed and discarded. Thus, in the food processing industry, mango peel ends up generally as a waste by-product. The present investigation was carried out to analyze the physical characteristics and biochemical composition of pulp and peel of mango varieties. From the study it was concluded that the physical parameters and biochemical composition varied in the variety and influenced the nutritional composition. The pulp and peel of three mango varieties differ among themselves in the length, width, breadth, acidity, waste generated and flavour. The information on composition of fruit and their edible wastes helps to understand the amount of nutrients which go a waste. The mango peel powder is a potential for food formulation because of its high content of nutrients, minerals, dietary

fiber, caroteine and bioactive compounds. The green gram laddu incorporated with kesar mango peel powder up to 15 per cent was significantly highly acceptable with acceptability index of 95.24 and contained higher $\beta$-carotene compared to the 
green gram laddu. Thus mango peel powder is edible and rich in nutrient and bioactive compounds can be used as a sprinkler or incorporated in variety of food preparations to enhance neutraceutical value of the foods. Development and utilization of such functional and nutritional products can be used to provide health benefits by preventing degenerative diseases.

\section{REFERENCES}

1. Abbott, J. A. (1999). Quality measurement of fruits and vegetables. Postharvest Biology and Technology, 15(3), 207-225.

2. Ajila, C., Rao, L. J., \& Rao, U. P. (2010). Characterization of bioactive compounds from raw and ripe Mangifera indica L. peel extracts. Food and Chemical Toxicology, 48(12), 3406-3411.

3. Ajila, C. M., Bhat, S. G., \& Prasada Rao, U. J. S. (2007). Valuable components of raw and ripe peels from two Indian mango varieties. Food Chemistry, 102(4), 1006-1011. doi: http://dx.doi.org/10.1016/j.foodchem.2006.06.036

4. Ajila, C. M., Jaganmohan Rao, L., \& Prasada Rao, U. J. S. (2010). Characterization of bioactive compounds from raw and ripe Mangifera indica L. peel extracts. Food and Chemical Toxicology, 48(12), 3406-3411. doi:http://dx.doi.org/10.1016/j.fct.2010.09.012

5. Ajila, C. M., Naidu, K. A., Bhat, S. G., \& Rao, U. J. S. P. (2007). Bioactive compounds and antioxidant potential of mango peel extract. Food Chemistry, 105(3), 982-988. doi: http://dx.doi.org/10.1016/j.foodchem.2007.04.052

6. Amerine, M., Pangborn, R., \& Roessler, E. (1965). Principles of sensory evaluation of food Academic press. New York/London.

7. AOAC 1995, Official methods of Analysis, Association of Official Analytical Chemists, $18^{\text {th }}$ edition, Washington, DC.

8. Berardini, N., Knödler, M., Schieber, A., \& Carle, R. (2005). Utilization of mango peels as a source of pectin and polyphenolics. Innovative Food Science \& Emerging Technologies, 6(4), 442-452. doi: http://dx.doi.org/10.1016/j.ifset.2005.06.004

9. Cavalcante, Í. H. L., Martins, A. B. G., de Sousa Miranda, J. M., \& Cavalcante, L. F. (2012). Physical and chemical characteristics of tropical and non-conventional fruits: INTECH Open Access Publisher.

10. Cook, R. (1999). An overview of key food industry drivers: implication for the fresh produce industry. Journal of Food Distribution Research, 30, 1-4.

11. Djantou, E., Mbofung, C. M., Scher, J., \& Desobry, S. (2007). A modelling approach to determine the effect of pre-treatment on the grinding ability of dried mangoes for powder production (Mangifera indica var Kent). Journal of food engineering, 80(2), 668-677.

12. Dye, W. (1956). Chemical studies on Halogeton glomeratus. Weeds, 55-60.

13. FAOSTAT. FAO Statistical DatabasesAgriculture, 2006; http:// apps.fao.org (accessed January, 2006).

14. Gopalan, C., Rama Sastri, B., \& Balasubramanian, S. (1971). Nutritive value of Indian foods.

15. Joseph, J., \& Abolaji, J. (1997). Effects of replacing maize with graded levels of cooked Nigerian mango-seed kernels (Mangifera indica) on the performance, carcass yield and meat quality of broiler chickens. Bioresource Technology, 61(1), 99-102.

16. Krishna, A. G., Khatoon, S., Shiela, P., Sarmandal, C., Indira, T., \& Mishra, A. (2001). Effect of refining of crude rice bran oil on the retention of oryzanol in the refined oil. Journal of the American Oil Chemists' Society, 78(2), 127-131. 
17. Larrauri, J. (1999). New approaches in the preparation of high dietary fibre powders from fruit by-products. Trends in Food Science \& Technology, 10(1), 3-8.

18. Larrauri, J. A., Rupérez, P., Borroto, B., \& Saura-Calixto, F. (1996). Mango peels as a new tropical fibre: preparation and characterization. LWT-Food Science and Technology, 29(8), 729-733.

19. Loeillet, D. (1994). The European mango market: A promising tropical fruit. Fruits, 49(5-6), 434-435.

20. Luthria, D. L. (2012). Optimization of extraction of phenolic acids from a vegetable waste product using a pressurized liquid extractor. Journal of Functional Foods, 4(4), 842-850.

21. Maran, J. P., Sivakumar, V., Thirugnanasambandham, K., \& Sridhar, R. (2014). Microwave assisted extraction of pectin from waste Citrullus lanatus fruit rinds. Carbohydrate polymers, 101, 786-791.

22. Oser, B. L. (1965). Hawk's physiological chemistry (Vol. 1040): McGraw-Hill New York.

23. Ranganna, S. (1986). Handbook of analysis and quality control for fruit and vegetable products: Tata McGraw-Hill Education.

24. Singha, K., Choudhary, R., \& Vishnu, K. (2014). Growth and Diversification of Horticulture Crops in Karnataka. SAGE Open, 4(3), 2158244014548018

25. Stafford, A. E. Mango. In Handbook of Tropical Fruits; Chan, H. T., Ed.; Marcel Dekker: New York, Basel, 1983; pp 399-431.

26. Wang, S., Chen, F., Wu, J., Wang, Z., Liao, X., \& Hu, X. (2007). Optimization of pectin extraction assisted by microwave from apple pomace using response surface methodology. Journal of food engineering, 78(2), 693-700.

27. Wheeler, E., \& Ferrel, R. (1971). Method for phytic acid determination in wheat and wheat fractions. Cereal chemistry.

28. Wolfe, K., Wu, X., \& Liu, R. H. (2003). Antioxidant activity of apple peels. Journal of Agricultural and Food Chemistry, 51(3), 609-614.

\section{APPENDICES}

Table 1: Physical Properties of Mango Fruits of Different Varieties

\begin{tabular}{|c|c|c|c|c|c|c|}
\hline \multirow{2}{*}{ Particulars } & \multicolumn{3}{|c|}{ Mango Varieties } & & \multirow{2}{*}{ SEm \pm} & \multirow{2}{*}{ CD } \\
\hline & Alphonso & Kesar & Totapuri & Mean & & \\
\hline Weight (g/fruit) & $231.90 \pm 29.92^{b}$ & $200.90 \pm 17.94^{c}$ & $287.00 \pm 16.81^{\mathrm{a}}$ & $239.93 \pm 42.15$ & 0.88 & $3.437 * *$ \\
\hline Volume (ml/ fruit) & $214.40 \pm 28.32^{b}$ & $188.80 \pm 17.99^{\mathrm{b}}$ & $261.50 \pm 20.13^{\mathrm{a}}$ & $221.57 \pm 37.59$ & 0.83 & $3.246^{* *}$ \\
\hline Bulk density (g/ml) & $1.08 \pm 0.02^{\mathrm{ab}}$ & $1.06 \pm 0.02^{b}$ & $1.10 \pm 0.03^{\mathrm{a}}$ & $1.08 \pm 0.03$ & 0.02 & $0.069 *$ \\
\hline Length $(\mathrm{cm})$ & $9.46 \pm 0.51^{b}$ & $9.57 \pm 0.51^{b}$ & $12.36 \pm 0.42^{\mathrm{a}}$ & $10.46 \pm 1.44$ & 0.51 & $2.011 * *$ \\
\hline Width $(\mathbf{c m})$ & $7.34 \pm 0.33^{\mathrm{a}}$ & $6.57 \pm 0.26^{b}$ & $7.08 \pm 0.17^{\mathrm{a}}$ & $6.99 \pm 0.41$ & 0.26 & $1.077 * *$ \\
\hline Breadth $(\mathbf{c m})$ & $6.06 \pm 1.21^{\mathrm{b}}$ & $5.80 \pm 0.18^{\mathrm{ab}}$ & $6.66 \pm 0.22^{\mathrm{a}}$ & $6.17 \pm 0.78$ & 0.38 & $1.097^{*}$ \\
\hline Weight of pulp (kg) & $\begin{array}{c}168.10 \pm 21.65^{b} \\
(72.488)\end{array}$ & $\begin{array}{c}140.20 \pm 12.37^{\mathrm{c}} \\
(69.786)\end{array}$ & $\begin{array}{c}190.30 \pm 13.36^{\mathrm{a}} \\
(66.307)\end{array}$ & $\begin{array}{c}166.20 \pm 26.13 \\
(69.270)\end{array}$ & 0.69 & $2.706^{* *}$ \\
\hline Weight of peel (kg) & $\begin{array}{l}32.00 \pm 6.96^{b} \\
(13.799)\end{array}$ & $\begin{array}{c}25.700 \pm 4.191^{b} \\
(12.792)\end{array}$ & $\begin{array}{c}43.80 \pm 14.12^{\mathrm{a}} \\
(15.261)\end{array}$ & $\begin{array}{c}33.83 \pm 11.86 \\
(14.101)\end{array}$ & 0.47 & $1.823^{* *}$ \\
\hline Weight of kernel (kg) & $\begin{array}{c}25.30 \pm 4.83^{\mathrm{c}} \\
(10.909)\end{array}$ & $\begin{array}{c}30.800 \pm 5.473^{b} \\
(15.331)\end{array}$ & $\begin{array}{l}32.70 \pm 5.93^{\mathrm{a}} \\
(11.393)\end{array}$ & $\begin{array}{c}29.60 \pm 6.13 \\
(9.836)\end{array}$ & 0.34 & $0.971 *$ \\
\hline Ratio of pulp : peel & 5.25 & 5.46 & 4.34 & 5.017 & - & - \\
\hline $\begin{array}{l}\text { Total edible waste } \\
\text { generated } \mathrm{kg} \text { (peel) }\end{array}$ & $32.00 \pm 6.960^{\mathrm{b}}$ & $25.700 \pm 4.191^{\mathrm{c}}$ & $\begin{array}{r}43.800 \pm \\
14.117^{\mathrm{a}}\end{array}$ & $\begin{array}{c}33.833 \pm \\
11.856\end{array}$ & 0.465 & $1.823^{* *}$ \\
\hline $\begin{array}{l}\text { Total waste generated } \\
\text { kg (Peel + kernel) }\end{array}$ & $57.30 \pm 10.843^{b}$ & $56.500 \pm 9.265^{b}$ & $\begin{array}{l}76.500 \pm \\
14.646^{\mathrm{a}}\end{array}$ & $\begin{array}{c}63.433 \pm \\
14.769\end{array}$ & 1.07 & $4.189 * *$ \\
\hline
\end{tabular}

Note 1: Values are mean of ten replications, SEm- Standard error of mean, CD- Critical difference, NS- Non Significant, * Significant @5\%,** Significant @ $1 \%$.Values with the same superscripts $(\mathrm{a}, \mathrm{b})$ in the same row are not significantly different $(\mathrm{p} \leq 0.01)$. Figures in parenthesis indicate percentage 
Table 2: Chemical Composition of Pulp and Peel of Mango Varieties

\begin{tabular}{|c|c|c|c|c|c|c|c|c|c|c|c|}
\hline \multirow{3}{*}{ Parameters } & \multicolumn{11}{|c|}{ Ilango Varieties } \\
\hline & \multicolumn{3}{|c|}{ Alphonso } & \multicolumn{3}{|c|}{ Kesar } & \multicolumn{3}{|c|}{ Totapuri } & \multicolumn{2}{|c|}{ Nean } \\
\hline & Pulp & Peel & Mean & Pulp & Peel & Nean & Pulp & Peel & Mean & Pulp & Peel \\
\hline $\mathrm{pH}$ & $4.10=0.10^{6}$ & . & . & $4.53 \pm 0.06^{\mathrm{B}}$ & . & $\cdot$ & $4.23 \pm 0.22^{16}$ & . & . & $4.29 \pm 0.12$ & . \\
\hline Titratable acidity (0\%) & $0.29 \pm 0.01$ & $0.13 \pm 0.01$ & $0.21 \pm 0.099^{2}$ & $0.22 \pm 0.00$ & $0.12 \pm 0.00$ & $0.16 \pm 0.055^{5}$ & $0.25 \pm 0.00$ & $0.12 \pm 0.01$ & $0.18 \pm 0.077^{\circ}$ & $0.25 \pm 0.0$ & $0.12 \pm 0.01$ \\
\hline Total soluble solids (Brix) & $19.80 \pm 1.59 \%$ &. & - & $21.93 \pm 0.57^{\mathrm{a}}$ & . & - & $17.17 \pm 0.15^{6}$ & . & - & $19.63 \pm 2.24$ &. \\
\hline Ascorbic acid(mgloligg) & $20.22 \pm 0.11$ & $28.39 \pm 0.55$ & $24.31 \pm 4.49^{2}$ & $18.52 \pm 0.35$ & $25.50 \pm 0.21$ & $22.01 \pm 3.836$ & $17.86 \pm 1.06$ & $24.08 \pm 0.16$ & $20.97 \pm 3.47^{6}$ & $18.87 \pm 1.20$ & $25.99 \pm 1.92$ \\
\hline Total sugarar (mg $/ 1 \mathrm{ing} \mathrm{g})$ & $19.32 \pm 0.31^{\mathrm{I}}$ & . & $\cdot$ & $15.75 \pm 0.44^{6}$ & . & . & $13.00 \pm 0.14^{\circ}$ & . & . & $16.03 \pm 2.76$ & . \\
\hline Reducing sugars (mg $100 \mathrm{~g}$ ) & $5.56 \pm 0.12^{2}$ & . & $\cdot$ & $4.15 \pm 0.15^{\circ}$ & . &. & $3.47 \pm 0.060^{6}$ & . & - & $4.40 \pm 0.93$ & . \\
\hline Von-Reducing sugaras (mg $1000 \mathrm{~g})$ & $13.76 \pm 0.19^{8}$ & . & $\cdot$ & $11.60 \pm 0.31^{b}$ & . & $\cdot$ & $9.53 \pm 0.18^{\circ}$ & . & $\cdot$ & $11.63 \pm 1.84$ & . \\
\hline Pectin $(\%)$ & $3.75 \pm 0.07$ & $19.40 \pm 0.12$ & $11.59 \pm 8.59^{6}$ & $6.05 \pm 0.14$ & $19.93 \pm 1.13$ & $12.99 \pm 7.64^{4}$ & $3.99 \pm 0.02$ & $17.43 \pm 0.19$ & $10.71 \pm 7.36$ & $4.59 \pm 1.10$ & $18.92 \pm 1.28$ \\
\hline
\end{tabular}

Note: The NS- Non Significant, * Significant at 0.05 per cent, ** Significant at 0.01 per cent

Table 3

\begin{tabular}{|c|c|c|c|c|c|c|}
\hline & SEm \pm & CD & & & SEm \pm & CD \\
\hline $\mathbf{p H}$ & 0.501 & $0.28 *$ & \multirow{3}{*}{$\begin{array}{l}\text { Titratable } \\
\text { Acidity }\end{array}$} & Portion & 0.015 & $0.05 *$ \\
\hline Total Soluble Solids & 0.498 & $2.612 * *$ & & Variety & 0.022 & $0.03 * *$ \\
\hline Total Sugars & 0.554 & $2.903 * *$ & & PxV & 0.037 & $0.15 * *$ \\
\hline Reducing Sugars & 0.363 & $1.905^{* *}$ & \multirow{3}{*}{ Ascorbic Acid } & Portion & 0.138 & $0.597 * *$ \\
\hline $\begin{array}{ll}\text { Non } & \text { Reducing } \\
\text { Sugars } & \end{array}$ & 0.453 & $2.374 * *$ & & Variety & 0.187 & $0.829 * *$ \\
\hline & & & & $\mathbf{P x V}$ & 0.315 & $1.361 * *$ \\
\hline & & & \multirow{3}{*}{ Pectin } & Portion & 0.132 & $0.571 * *$ \\
\hline & & & & Variety & 0.179 & $0.775 * *$ \\
\hline & & & & PxV & 0.302 & $1.303 * *$ \\
\hline
\end{tabular}

Note 1: Values are mean of ten replications, SEm- Standard error of mean, CD- Critical difference, NS- Non Significant, * Significant @ 5\%,** Significant @ $1 \%$.Values with the same superscripts (a, b) in the same row are not significantly different $(\mathrm{p} \leq 0.01)$.

Table 4: Proximate Composition and Energy of Pulp and Peel of Mango

\begin{tabular}{|c|c|c|c|c|c|c|c|c|}
\hline \multirow{2}{*}{$\begin{array}{l}\text { Portion } \\
\text { of Fruit }\end{array}$} & \multirow{2}{*}{$\begin{array}{c}\text { Mango } \\
\text { Varieties }\end{array}$} & \multicolumn{7}{|c|}{ Proximate Composition (\% Dwb) } \\
\hline & & Moisture & Protein & Fat & $\begin{array}{c}\text { Total } \\
\text { Minerals }\end{array}$ & Crude Fibre & Carbohydrate & $\begin{array}{c}\text { Energy } \\
\text { (Kcal } 100 \mathrm{~g})\end{array}$ \\
\hline \multirow[t]{3}{*}{ Pulp } & Alphonso & $83.19 \pm 0.02$ & $0.73 \pm 0.03$ & $0.82 \pm 0.15$ & $2.32 \pm 0.07$ & $0.68 \pm 0.03$ & $12.25 \pm 0.10$ & $59 \pm 0899$ \\
\hline & Kesar & $76.09 \pm 0.15$ & $0.98 \pm 0.12$ & $0.65 \pm 0.04$ & $1.52 \pm 0.06$ & $0.32 \pm 0.03$ & $20.44 \pm 0.27$ & $92 \pm 0,632$ \\
\hline & Totapuri & $72.94 \pm 0.11$ & $0.59 \pm 0.02$ & $0.77 \pm 0.11$ & $1.88 \pm 0.05$ & $0.56 \pm 0.02$ & $23.32 \pm 0.08$ & $103 \pm 1.081$ \\
\hline \multicolumn{2}{|c|}{ Mean of pulp } & $77.41 \pm 4.55$ & $0.77 \pm 0.18$ & $0.75 \pm 0.12$ & $1.89 \pm 0.35$ & $0.52 \pm 0.16$ & $18.67 \pm 4.98$ & $85 \pm 19.462$ \\
\hline \multirow[t]{3}{*}{ Peel } & Alphonso & $10.32 \pm 0.95$ & $0.86 \pm 0.13$ & $3.15 \pm 0.059$ & $3.41 \pm 0.04$ & $10.91 \pm 0.85$ & $71.35 \pm 0.80$ & $317 \pm 2.810$ \\
\hline & Kesar & $10.40 \pm 0.15$ & $0.36 \pm 0.05$ & $3.72 \pm 0.05$ & $3.75 \pm 0.09$ & $10.72 \pm 0.16$ & $71.05 \pm 0.36$ & $319 \pm 1.299$ \\
\hline & Totapuri & $10.56 \pm 0.24$ & $0.86 \pm 0.25$ & $3.88 \pm 0.03$ & $3.32 \pm 0.05$ & $10.20 \pm 0.08$ & $71.17 \pm 0.22$ & $323 \pm 0.561$ \\
\hline \multicolumn{2}{|c|}{ Mean of peel } & $10.43 \pm 0.18$ & $0.69 \pm 0.26$ & $3.59 \pm 0.34$ & $3.49 \pm 0.21$ & $10.61 \pm 0.54$ & $71.19 \pm 0.47$ & $320 \pm 3.033$ \\
\hline \multirow{3}{*}{$\begin{array}{l}\text { Mean of } \\
\text { variety }\end{array}$} & Alphonso & $46.71 \pm 44.02^{\mathrm{a}}$ & $0.79 \pm 0.12^{a}$ & $1.99 \pm 1.28^{\mathrm{b}}$ & $2.87 \pm 0.60^{\mathrm{a}}$ & $5.79 \pm 5.63^{\mathrm{a}}$ & $45.55 \pm 36.48^{c}$ & $203 \pm 157.67^{c}$ \\
\hline & Kesar & $43.20 \pm 40.05^{b}$ & $0.67 \pm 0.35^{a}$ & $2.19 \pm 1.68^{\mathrm{a}}$ & $2.64 \pm 1.22^{b}$ & $5.38 \pm 5.28^{\mathrm{a}}$ & $49.46 \pm 31.79^{\mathrm{a}}$ & $220 \pm 140.95^{b}$ \\
\hline & Totapuri & $41.75 \pm 38.77^{c}$ & $0.73 \pm 0.15^{\mathrm{a}}$ & $2.33 \pm 1.71^{\mathrm{a}}$ & $2.57 \pm 0.82^{b}$ & $5.57 \pm 5.20^{\mathrm{a}}$ & $4882 \pm 31.21^{b}$ & $230 \pm 139.23^{\mathrm{a}}$ \\
\hline \multicolumn{2}{|c|}{ Total } & $43.92 \pm 34.60$ & $0.73 \pm 0.222$ & $2.17 \pm 1.48$ & $2.69 \pm 0.87$ & $5.57 \pm 5.20$ & $44.93 \pm 27.24$ & $202 \pm 121.831$ \\
\hline
\end{tabular}


Table 5

\begin{tabular}{|c|c|c|c|c|c|c|c|c|}
\hline & & Moisture & Protein & Fat & Minerals & Fiber & CHO & Calories \\
\hline \multirow{2}{*}{ Factor A } & SEM & 0.073 & 0.054 & 0.056 & 0.048 & 0.115 & 0.11 & 0.23 \\
\hline & CD & $0.073 * *$ & NS & $0.241 * *$ & $0.208 * *$ & $0.495 * *$ & $0.477 * *$ & $0.974 * *$ \\
\hline \multirow{2}{*}{ Factor B } & SEM & 0.10 & 0.073 & 0.075 & 0.065 & 0.155 & 0.148 & 0.311 \\
\hline & CD & $0.425 * *$ & NS & $0.325 * *$ & $0.284 * *$ & NS & $0.640 * *$ & $1.347 * *$ \\
\hline \multirow{2}{*}{$A \times B$} & SEM & 2121 & 0.123 & 0.126 & 0.110 & 0.261 & 0.225 & 0.525 \\
\hline & CD & $0.714 * *$ & $0.529 * *$ & $0.546^{* *}$ & $0.473 * *$ & NS & $0.972 * *$ & $2.266 * *$ \\
\hline
\end{tabular}

Note1: Values are mean of three replications, SEm- Standard error of mean, CD- Critical difference, NS- Non Significant, ** Significant @ $1 \%$.Values with the same superscripts (a, b, c) in the same column are not significantly different $(\mathrm{p} \leq 0.01)$,

Note2: Factor A- Between portion of fruit (pulp and peel), Factor B- Between Variety (Alphonso, Kesar, Totapuri)

Table 6: Mineral Content (Mg/100g) of Pulp and Peel of Mango

\begin{tabular}{|c|c|c|c|c|c|c|c|}
\hline Mz & arieties & Calcium & Phosphorus & Zinc & Iron & Manganese & Copper \\
\hline \multirow{3}{*}{ Pulp } & Alphonso & $12.30 \pm 0.12$ & $15.68 \pm 0.31$ & $0.19 \pm 0.023$ & $0.26 \pm 0.03$ & $0.16 \pm 0.05$ & $0.05 \pm 0.01$ \\
\hline & Kesar & $13.46 \pm 0.32$ & $16.40 \pm 0.30$ & $0.21 \pm 0.034$ & $0.35 \pm 0.05$ & $0.17 \pm 0.01$ & $0.30 \pm 0.01$ \\
\hline & Totapu & $12.54 \pm 0.02$ & $15.13 \pm 0.11$ & $0.18 \pm 0.019$ & $0.22 \pm 0.00$ & $0.13 \pm 0.03$ & $0.04 \pm 0.01$ \\
\hline \multicolumn{2}{|c|}{ Mean of Pulp } & $12.77 \pm 0.56$ & $15.73 \pm 0.60$ & $0.19 \pm 0.0264$ & $0.28 \pm 0.07$ & $0.15 \pm 0.03$ & $0.04 \pm 0.01$ \\
\hline \multirow{3}{*}{ Peel } & Alphonso & $18.57 \pm 0.09$ & $20.95 \pm 0.06$ & $0.19 \pm 0.000$ & $0.48 \pm 0.03$ & $0.25 \pm 0.01$ & $0.04 \pm 0.00$ \\
\hline & Kesar & $17.76 \pm 0.19$ & $19.06 \pm 0.02$ & $0.29 \pm 0.093$ & $0.58 \pm 0.20$ & $0.34 \pm 0.02$ & $0.11 \pm 0.02$ \\
\hline & & $17.82 \pm 0.14$ & $19.44 \pm 0.71$ & $0.205 \pm 0.068$ & $0.42 \pm 0.06$ & $0.53 \pm 0.07$ & 0.03 \\
\hline \multicolumn{2}{|c|}{ Mean of peel } & $18.05 \pm 0.41$ & $19.82 \pm 0.94$ & $0.228 \pm 0.075$ & $0.49 \pm 0.13$ & $0.37 \pm 0.13$ & 0.04 \\
\hline \multirow{3}{*}{$\begin{array}{l}\text { Mean of } \\
\text { Variety }\end{array}$} & Alp & $\begin{array}{c}15.43 \pm \\
3.44^{\text {ab }}\end{array}$ & $\begin{array}{c}18.31 \pm \\
2.90^{\mathrm{a}}\end{array}$ & $0.19 \pm 0.014^{a}$ & $0.37 \pm 0.13^{\mathrm{a}}$ & $0.21 \pm 0.05^{\mathrm{c}}$ & $0.05 \pm 0.01^{b}$ \\
\hline & Kesar & $15.61 \pm \underset{a}{2.37}$ & $\begin{array}{c}17.73 \pm \\
1.47^{\mathrm{ab}} \\
\end{array}$ & $0.25 \pm 0.077^{\mathrm{a}}$ & $0.46 \pm 0.18^{a}$ & $0.26 \pm 0.10^{b}$ & $0.07 \pm 0.05^{a}$ \\
\hline & Totapuri & $\begin{array}{c}15.18 \pm \\
2.89^{b}\end{array}$ & $\begin{array}{c}17.28 \pm \\
2.41^{b}\end{array}$ & $0.19 \pm 0.05^{\mathrm{a}}$ & $0.31 \pm 0.11^{\mathrm{a}}$ & $\begin{array}{c}\mathbf{0 . 3 3 0} \pm \\
\mathbf{0 . 2 3}^{\mathrm{a}}\end{array}$ & $0.05 \pm 0.02^{b}$ \\
\hline $\begin{array}{l}\text { Grand } \\
\text { mean }\end{array}$ & & $15.41 \pm 2.76$ & $17.78 \pm 2.23$ & $0.21 \pm 0.06$ & $0.39 \pm 0.15$ & $0.26 \pm 0.15$ & $0.06 \pm 0.03$ \\
\hline
\end{tabular}

Table 7

\begin{tabular}{|c|c|c|c|c|c|c|c|}
\hline & & $\mathrm{Ca}$ & $\mathbf{P}$ & $\mathrm{Zn}$ & $\mathrm{Fe}$ & Mn & $\mathrm{Cu}$ \\
\hline \multirow{2}{*}{ Portion } & SEm \pm & 0.080 & 0.113 & 0.026 & 0.151 & 0.156 & 0.021 \\
\hline & CD & $0.347 * *$ & $0.486^{* *}$ & NS & NS & $0.674 * *$ & $0.091 * *$ \\
\hline \multirow{2}{*}{ Variety } & SEm \pm & 0.109 & 0.152 & 0.037 & 0.074 & 0.063 & 0.013 \\
\hline & CD & $0.335 * *$ & $0.658 * *$ & NS & 0 & $0.273 * *$ & NS \\
\hline \multirow{2}{*}{$\begin{array}{l}\text { Portion } \mathbf{x} \\
\text { Variety }\end{array}$} & SEm \pm & 0.183 & 0.256 & 0.032 & 0.00 & 0.117 & 0.03 \\
\hline & CD & $0.789 * *$ & $1.107 * *$ & NS & NS & $0.505 * *$ & 0.137 ** \\
\hline
\end{tabular}

Note: Values are mean of three replications, SEm- Standard error of mean, CD- Critical difference, IDFInsoluble dietary fiber, SDF- Soluble dietary fiber, TDF- Total Soluble fiber,** Significant @ $1 \%$.Values with the same superscripts $(a, b, c)$ in the same column are not significantly different $(p \leq 0.01)$. 
Table 8: Antinutrient Content of Pulp and Peel of Mango

\begin{tabular}{|c|c|c|c|c|c|c|}
\hline \multirow{2}{*}{$\begin{array}{c}\text { Mango } \\
\text { Varieties }\end{array}$} & \multicolumn{3}{|c|}{ Phytic acid (mg/100g) } & \multicolumn{3}{|c|}{ Oxalates (\%) } \\
\hline & Pulp & Peel & Mean B & Pulp & Peel & Mean B \\
\hline Alphonso & $0.59 \pm 0.11$ & $25.53 \pm 4.44$ & $13.06 \pm 13.95^{\mathrm{ab}}$ & $4.33 \pm 0.03$ & $5.95 \pm 0.11$ & $5.14 \pm 0.890^{c}$ \\
\hline Kesar & $0.64 \pm 0.17$ & $33.70 \pm 6.17$ & $17.17 \pm 18.53^{\mathrm{a}}$ & $4.06 \pm 0.01$ & $8.98 \pm 0.19$ & $6.52 \pm 2.695^{\mathrm{a}}$ \\
\hline Totapuri & $0.60 \pm 0.10$ & $17.20 \pm 5.81$ & $8.90 \pm 9.81^{b}$ & $4.54 \pm 0.09$ & $6.78 \pm 0.10$ & $5.66 \pm 1.235^{b}$ \\
\hline Mean A & $0.61 \pm 0.11$ & $25.48 \pm 8.60$ & $13.04 \pm 14.09$ & $4.31 \pm 0.21$ & $7.24 \pm 1.36$ & $5.77 \pm 1.778$ \\
\hline
\end{tabular}

Table 9

\begin{tabular}{|l|c|c|c|c|}
\hline \multicolumn{1}{|c|}{ Mango } & \multicolumn{2}{|c|}{ Phytic acid } & \multicolumn{2}{c|}{ Oxalates } \\
\hline & SEm \pm & CD & SEm \pm & CD \\
\hline Factor A & 0.381 & $1.644^{*}$ & 0.062 & $0.269^{* *}$ \\
\hline Factor B & 0.516 & $1.589^{*}$ & 0.085 & $0.366^{* *}$ \\
\hline A x B & 0.867 & $2.673^{*}$ & 0.141 & $0.611^{* *}$ \\
\hline
\end{tabular}

Table 10: Optimization of Green Gram Laddu Incorporated with Kesar Mango Peel

\begin{tabular}{|c|c|c|c|c|c|c|c|c|}
\hline $\begin{array}{c}\text { Green Gram } \\
\text { Flour: Mango } \\
\text { Peel } \\
\end{array}$ & Appearance & Colour & Texture & Aroma & Flavour & Taste & $\begin{array}{c}\text { Overall } \\
\text { Acceptability }\end{array}$ & $\begin{array}{l}\text { Acceptability } \\
\text { Index }\end{array}$ \\
\hline 100:0 & $8.00 \pm 0.14^{\mathrm{a}}$ & $\begin{array}{c}8.10 \\
\pm 0.52^{\mathrm{ab}}\end{array}$ & $\begin{array}{c}8.00 \\
\pm 0.57^{\mathrm{ab}}\end{array}$ & $\begin{array}{l}7.80 \pm \\
0.91^{\mathrm{b}}\end{array}$ & $\begin{array}{l}7.50 \pm \\
0.81^{\mathrm{b}}\end{array}$ & $\begin{array}{c}7.90 \\
\pm 0.32^{\mathrm{b}}\end{array}$ & $7.70 \pm 0.60^{b}$ & $87.30 \pm 6.83^{b}$ \\
\hline 95:05 & $8.60 \pm 0.52^{\mathrm{a}}$ & $\begin{array}{c}8.70 \pm \\
0.48^{\mathrm{a}}\end{array}$ & $\begin{array}{l}8.40 \pm \\
0.70^{\mathrm{ab}}\end{array}$ & $\begin{array}{l}8.30 \pm \\
0.82^{\mathrm{ab}}\end{array}$ & $\begin{array}{l}8.30 \pm \\
0.68^{\mathrm{ab}}\end{array}$ & $\begin{array}{l}8.10 \pm \\
0.74^{\mathrm{ab}}\end{array}$ & $8.30 \pm 0.68^{\mathrm{ab}}$ & $93.18 \pm 5.45^{\mathrm{ab}}$ \\
\hline 90:10 & $8.60 \pm 0.52^{a}$ & $\begin{array}{c}8.60 \pm \\
0.52^{\mathrm{a}}\end{array}$ & $\begin{array}{c}8.70 \\
\pm 0.48^{\mathrm{a}}\end{array}$ & $\begin{array}{l}8.30 \pm \\
0.82^{\mathrm{ab}}\end{array}$ & $\begin{array}{l}8.20 \pm \\
1.03^{\mathrm{ab}}\end{array}$ & $\begin{array}{l}8.50 \pm \\
0.71^{\mathrm{ab}}\end{array}$ & $8.50 \pm 0.71^{\mathrm{ab}}$ & $94.29 \pm 6.68^{\mathrm{a}}$ \\
\hline $85: 15$ & $8.20 \pm 0.42^{a}$ & $\begin{array}{l}8.30 \pm \\
0.48^{\mathrm{ab}}\end{array}$ & $\begin{array}{l}8.50 \pm \\
0.53^{\mathrm{ab}}\end{array}$ & $\begin{array}{c}8.60 \pm \\
0.70^{\mathrm{a}}\end{array}$ & $\begin{array}{c}8.80 \pm \\
0.42^{\mathrm{a}}\end{array}$ & $\begin{array}{c}8.80 \pm \\
0.42^{\mathrm{a}} \\
\end{array}$ & $8.80 \pm 0.42^{\mathrm{a}}$ & $95.24 \pm 4.17^{\mathrm{a}}$ \\
\hline $80: 20$ & $8.00 \pm 0.94^{\mathrm{a}}$ & $\begin{array}{c}7.70 \pm \\
1.06^{\mathrm{b}} \\
\end{array}$ & $\begin{array}{l}7.80 \pm \\
0.63^{\mathrm{b}} \\
\end{array}$ & $\begin{array}{l}7.60 \pm \\
0.70^{\mathrm{b}}\end{array}$ & $\begin{array}{l}7.70 \pm \\
0.95^{\mathrm{b}} \\
\end{array}$ & $\begin{array}{l}7.80 \pm \\
0.79^{\mathrm{b}} \\
\end{array}$ & $7.70 \pm 0.82^{b}$ & $86.19 \pm 8.20^{\mathrm{b}}$ \\
\hline Total Mean & $8.35 \pm 0.66$ & $\begin{array}{c}8.33 \pm \\
0.76 \\
\end{array}$ & $\begin{array}{c}8.35 \pm \\
0.66 \\
\end{array}$ & $\begin{array}{c}8.20 \pm \\
0.82\end{array}$ & $\begin{array}{c}8.25 \pm \\
0.87 \\
\end{array}$ & $\begin{array}{c}8.30 \pm \\
0.76\end{array}$ & $8.33 \pm 0.76$ & $92.22 \pm 7.04$ \\
\hline 'F' value & 2.250 & 4.365 & 4.286 & 3.086 & 3.128 & 4.193 & 4.767 & 4.257 \\
\hline SEM \pm & 0.102 & 0.110 & 0.102 & 0.114 & 0.117 & 0.109 & 0.110 & 0.337 \\
\hline CD & NS & 0.315* & 0.293* & 0.327* & 0.336* & 0.314* & $0.423 * *$ & 0.966* \\
\hline
\end{tabular}

Note: Values are mean of three replications, SEm- Standard error of mean, CD- Critical difference, NS- Non Significant,

* Significant@5\%,** Significant@ @ $1 \%$.Values with the same superscripts (a, b, c) in the same column are not significantly different $(\mathrm{p} \leq 0.01)$

Table 11: Organoleptic Evaluation of Green Gram Laddu Incorporated with Mango Peel

\begin{tabular}{|c|c|c|c|c|c|c|c|c|}
\hline $\begin{array}{c}\text { Mango peel } \\
\text { Incorporated } \\
\text { laddu }\end{array}$ & Appearance & Colour & Texture & Aroma & Flavour & Taste & $\begin{array}{c}\text { Overall } \\
\text { Acceptability }\end{array}$ & $\begin{array}{l}\text { Acceptability } \\
\text { Index }\end{array}$ \\
\hline Alphonso & $7.80 \pm 0.63^{\mathrm{a}}$ & $7.20 \pm 0.42^{\mathrm{b}}$ & $6.60 \pm 0.52^{\mathrm{b}}$ & $7.20 \pm 0.79^{\mathrm{b}}$ & $\begin{array}{ll}7.40 & \pm \\
0.97^{\mathrm{b}} & \end{array}$ & $7.40 \pm 0.97^{\mathrm{a}}$ & $7.50 \pm 0.53^{b}$ & $80.80 \pm 3.55^{b}$ \\
\hline Kesar & $8.20 \pm 0.42^{\mathrm{a}}$ & $8.30 \pm 0.48^{\mathrm{ab}}$ & $8.50 \pm 0.53^{a b}$ & $8.60 \pm 0.70^{\mathrm{a}}$ & $\begin{array}{ll}8.80 & \pm \\
0.42^{\mathrm{a}} & \end{array}$ & $8.80 \pm 0.42^{\mathrm{a}}$ & $8.80 \pm 0.42^{\mathrm{a}}$ & $95.24 \pm 4.17^{\mathrm{a}}$ \\
\hline Totapuri & $7.90 \pm 0.88^{\mathrm{a}}$ & $7.70 \pm 0.48^{\mathrm{a}}$ & $7.30 \pm 0.48^{\mathrm{a}}$ & $7.50 \pm 0.53^{\mathrm{ab}}$ & $\begin{array}{ll}7.30 & \pm \\
0.95^{\mathrm{b}} & \end{array}$ & $7.60 \pm 1.17^{\mathrm{a}}$ & $7.70 \pm 0.48^{\mathrm{ab}}$ & $84.13 \pm 4.49^{\mathrm{a}}$ \\
\hline Grand Mean & $7.97 \pm 0.77$ & $7.53 \pm 0.51$ & $7.03 \pm 0.56$ & $7.53 \pm 0.73$ & $7.70 \pm 0.99$ & $7.47 \pm 0.90$ & $7.80 \pm 0.61$ & $86.33 \pm 4.54$ \\
\hline 'F' value & 0.727 & 3.879 & 6.344 & 2.562 & 10.230 & 0.155 & 4.280 & 8.639 \\
\hline SEM \pm & 0.118 & 0.096 & 0.101 & 0.115 & 0.134 & 0.128 & 0.106 & 0.288 \\
\hline CD & NS & 0.279* & $0.395 * *$ & 0.335* & $0.526 * *$ & NS & 0.306* & $1.128 * *$ \\
\hline
\end{tabular}

Note: Values are mean of three replications, SEm- Standard error of mean, CD- Critical difference, NS- Non Significant,

* Significant@5\%,** Significant @ $1 \%$.Values with the same superscripts (a, b, c) in the same column are not significantly different $(\mathrm{p} \leq 0.01)$ 
Table 12: Effect of Incorporation of Mango Peel Powder on Nutrient Composition of Green Gram Laddu

\begin{tabular}{|l|c|c|}
\hline Nutrients ( per 100g) & $\begin{array}{c}\text { Green Gram } \\
\text { Laddu }\end{array}$ & $\begin{array}{c}\text { Green Gram } \\
\text { Ladduincorporated with } \\
\text { Mango Peel Powder }\end{array}$ \\
\hline Moisture & 13.02 & 13.69 \\
\hline Protein & 13.19 & 11.26 \\
\hline Fat & 12.06 & 12.62 \\
\hline Crude fiber & 4.65 & 5.55 \\
\hline Carbohydrate & 54.86 & 65.52 \\
\hline Energy (Kcal) & 439 & 421 \\
\hline B-Carotene ( $\mathbf{\mu g} / \mathbf{1 0 0 g})$ & 44.2 & 202.39 \\
\hline Calcium $(\mathbf{m g / 1 0 0 g )}$ & 40.54 & 37.11 \\
\hline Phosphorus (mg/100g) & 132.92 & 188.94 \\
\hline Zinc (mg/100g) & 1.51 & 1.32 \\
\hline Iron (mg/100g) & 1.87 & 2.11 \\
\hline Manganese (mg/100g) & 0.66 & 0.73 \\
\hline Copper (mg/100g) & 0.67 & 0.78 \\
\hline
\end{tabular}

* Kesar variety peel powder @ 15\%

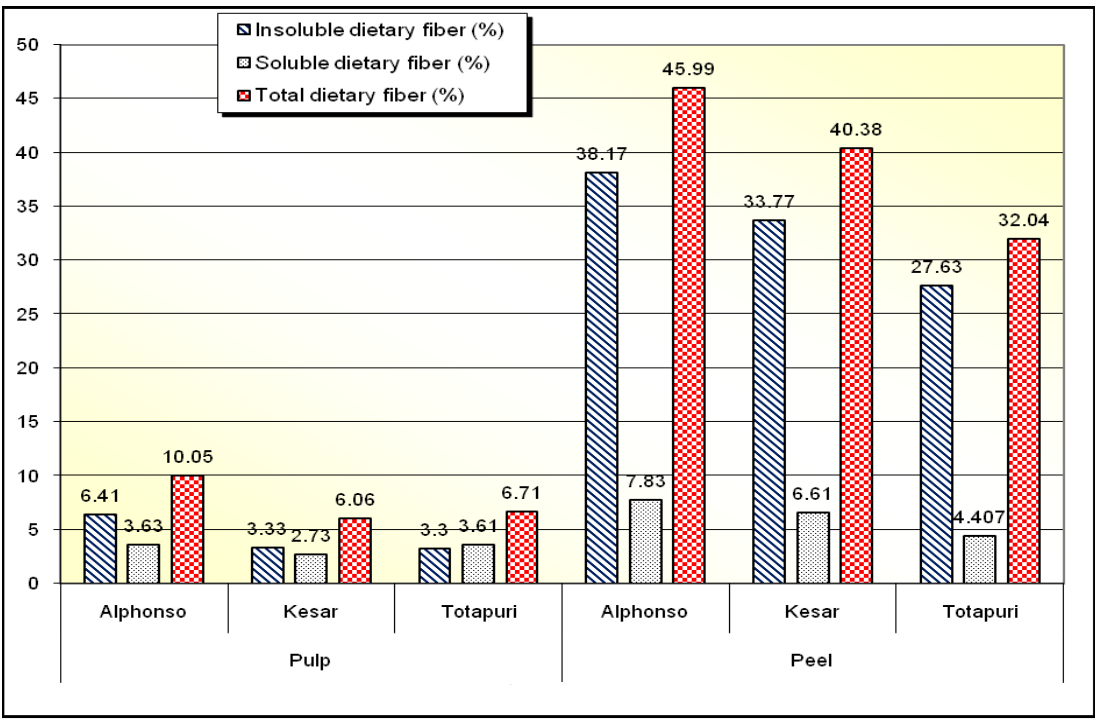

Figure 1: Dietry Fiber Content of Pulp and Peel of Mango

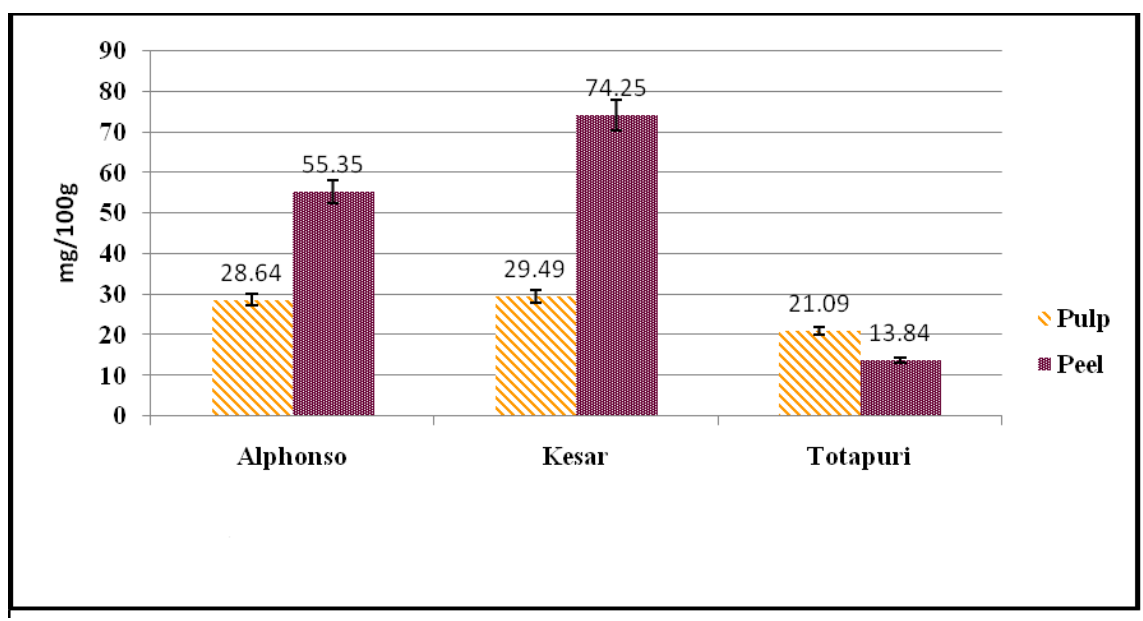

Figure 2: B-Carotene Content of Pulp and Peel of Mango Varieties 